\title{
Book Review: Words, Music and Gender (Michelle Gadpaille and Victor Kennedy, eds.)
}

Jack is in his corset, Jane is in her vest... And me, I'm in a rock 'n' roll band -Lou Reed, "Sweet Jane"1

Words, Music and Gender is a collection of 17 contributions by scholars hailing from a variety of academic backgrounds, enabling the volume to cover an impressive array of ways in which gender, words and music intersect and intertwine, affect and challenge each other in relationships that frequently reflect broader societal concerns. The editors, Michelle Gadpaille and Victor Kennedy, are no novices to the field, having not only themselves authored publications on the convergence of language and music (see e.g. Kennedy's Strange Brew: Metaphors of Magic and Science in Rock Music from 2013), but presently also delighting us with what is already the fourth monograph in a series of interdisciplinary studies on the matter (succeeding Words and Music (2013), Symphony and Song: The Intersection of Words and Music (2016) and Ethnic and Cultural Identity in Music and Song Lyrics (2017)). The latest tome offers a welcome continuation to this sequence, with its focus predominantly on gender, sexism, misogyny and sexuality in the world of music and music-related literature. The experienced editors were successful in putting together a notably coherent unit wherein individual papers shrewdly follow each other most of the time, in spite of their extremely varied content.

The musical journey begins with the reader being pushed straight into the deep end of the scintillating pool of rock, with what I find to be two of the most compelling undertakings in this collection. Mojca Krevel's lucid exploration of David Bowie's sexual fluidity and gender-bending performances goes beyond the artist's importance as a chameleonic LGBTQ icon, and asserts his position as a transgressive postmodern composite, a pioneer of the non-binary, master of fractal subjectivity and "intrinsic to the formation of identity within the ontological framework of postmodernity" (2020, 7). Equally impassioned and intriguing is Melanija Larisa Fabčičs piece on the rock goddess Kim Gordon, in which the author explores the Sonic Youth singer and guitarist's understanding and use of lyrics (and their delivery in particular) as tools with which to (re)conceptualize gender and deterritorialize it in the Deleuzian sense.

Lessons at the school of rock continue with Dolores Hunsky's absorbing and concise, yet vexatiously less thorough, overview of Joan Jett's career and her contribution to gender equality, and Victor Kennedy's illuminating insight into the Canadian New Wave, which

Reed, Lou. 1970. “Sweet Jane.” Track 2 on Loaded. The Velvet Underground. New York City: Cotillion Records. 
provides the reader with many examples of the role the genre (and bands such as Rough Trade and Pukka Orchestra in particular) played in the development of "new forms of personal identity through criticism of older, binary gender and authority roles" $(2020,85)$. Before venturing into the stereotypically male worlds of rap and metal, a foray into glam metal by Ana Maiken Kores acts as an interesting intermediary that, through meticulous analysis of Mötley Crüe lyrics, exposes the oxymoronic nature of a genre that provides a platform for gender experimentation and is, at the same time, also a breeding ground for extreme misogyny.

Jožef Kolarič acquaints the reader with some examples of homophobia in rap music and argues that the genre is not inherently homophobic, but is likely to exhibit homophobic tendencies due to the influence of the musicians upbringing and social influences. Theauthor concludes that rap is actually becoming less homophobic - an intriguing hypothesis that is briefly discussed in the paper and will hopefully be further explored by the author in the future. Bojan Kašuba's segment offers a linguistic intermission that would perhaps be better placed as the text linking the musical and the literary parts of the monograph, but fo' shizzle makes for an engaging read on new lexical items entering English vocabulary through music.

After this somewhat unfortunately positioned detour, Words, Music and Gender takes the reader back to analyses of different musical genres with three contributions that focus on the role of women in music. Tina Ritlop opens a gutsy discussion on female growls and screams in metal with an exciting piece that would nevertheless benefit greatly from being expanded with additional research and examples. The volume narrowly avoids being called out for focusing purely on Western music production by including an informative piece by Marged Flavia Trumper on the Hindustani genre of thumri and its role as a tool of affirmation for female singers in Northern Indian society. While such single entries do tend to have the inexorable scent of tokenism wafting about them, Trumper's contribution gives the reader at least a (wonderfully moreish) taste of the vast musical landscapes that are yet to be tackled by scholars to an extent comparable to that of their Western counterparts. Zmago Pavličič concludes the first part of the volume with an original and orderly investigation into the history of female jazz musicians in Slovenia.

The second part of the publication consists of seven texts dealing with music and gender in a literary context, covering diverse examples from prose, poetry and drama. F. Zeynep Bilge and Michelle Gadpaille both sink their proverbial teeth into Shakespeare, one by examining Ophelia's thought-provoking portrayal in a French operatic adaptation of Hamlet, the other by uncovering the importance of the Bard's musical puns (in combination with Elizabethan theatrical gender conventions), as "they simultaneously foreground gender difference, draw attention to gender norms and their breach and permit the staging of sexual arousal for both homo- and hetero-sexual viewers" $(2020,211)$. Ana Penjak, Jason Blake and Tjaša Mohar also delve fruitfully into three distinctly different literary texts (Joyce's classic "The Dead", Miriam Toews's novel A Complicated Kindness and Alice Munro's short story "TheBear Came Over the Mountain"), as they analyse the influence of assorted musical elements, events and references on narration, character portrayal, the setting (both temporal and spatial), interpretation and numerous other aspects of literary worlds. Jerneja Planinšek-Žlof and Nastja Prajnc Kacijan 
perform equally rewarding music-themed dissections of Tennessee William's seminal play Cat on a Hot Tin Roof and Adrienne Rich's poem "Transcendental Etude", thus concluding the reader's journey in style.

One of the volume's most attractive qualities is the fact that an impressive number of the authors are themselves not only scholars but also performing musicians, and therefore uniquely equipped with an additional perspective that enriches many of the contributions. However, as with most volumes that come to life as a result of interdisciplinary conferences, Words, Music and Gender struggles somewhat with uniformity and its individual parts can vary greatly in length, ambition, purpose and attention to detail, as well as in quality of writing and research. Some of the authors engage with the gender aspect much more than others, yet most manage to offer a pleasing amalgamation of the three key components highlighted in the collection's title. Overall, the volume is a strong addition to the series that competently continues the mission of its predecessors, with many of the segments representing an important contribution to both gender and music studies, and will certainly be read with relish by scholars across the humanities, musicians and music lovers alike.

\section{References}

Gadpaille, Michelle, and Victor Kennedy, eds. 2020. Words, Music and Gender. Newcastle upon Tyne: Cambridge Scholars Publishing.

Kennedy, Victor. 2013. Strange Brew: Metaphors of Magic and Science in Rock Music. Newcastle upon Tyne: Cambridge Scholars Publishing.

Kennedy, Victor, and Michelle Gadpaille, eds. 2013. Words and Music. Newcastle upon Tyne: Cambridge Scholars Publishing.

- 2016. Symphony and Song: The Intersection of Words and Music. Newcastle upon Tyne: Cambridge Scholars Publishing.

- 2017. Ethnic and Cultural Identity in Music and Song Lyrics. Newcastle upon Tyne: Cambridge Scholars Publishing. 